\title{
Are Czech and Estonian Companies Willing To Publicly Present Their Financial Statements? Evidence from Czech and Estonian TOP100
}

\author{
Jiř́ Strouhal, Monika Nikitina-Kalamäe, and Natalja Gurvitš
}

\begin{abstract}
At the end of the accounting period all statutory audited business entities have to prepare and submit to the business register the annual report - the on-time submission of the financial statements is of a high importance for all stakeholders to be able to make proper economical decisions. This paper represents the examination of how the implementation of the e-submissions of financial statements has influenced the on-time submission by the selected companies. In order to determine whether e- system influenced positively the on-time submission of annual reports authors have selected the annual reports submitted to the Czech and Estonian Business Register by the most successful TOP100 Czech and Estonian companies for the period 2007-2011. The results revealed that the number of the on time submitted annual reports has increased significantly after the implementation of the new Estonian e-reporting system, however Czech companies still are not very willing to submit their financial statements on time.
\end{abstract}

Index Terms-Annual report, presentation, TOP100, Czech Republic, Estonia.

\section{INTRODUCTION AND SOME BRIEF LITERATURE REVIEW ON APPROACHED RESEARCH AREA}

Due to the globalisation of capital markets the demand for disclosure of listed companies has increased and the failures of large companies listed on the most important financial markets have placed extra pressure on both listed companies as well as standard setters to increase the quality of corporate reporting [1]

Many researchers have focused their studies on the accounting mandatory disclosure [2]-[5] mainly because of the exactly specified regulations that provide the content, the format of information and the variety of the data included in the financial statements.

On the other hand significant group of researchers have focused their studies on accounting voluntary disclosure because the disclosure of other corporate reports in addition to the minimum requirements, could reduce information asymmetry and agency conflicts between managers and outside investors [6]-[8]. Healy and Palepu [6] analyze managers' reporting and disclosure decisions in a capital markets setting. They believe that six forces affect managers' disclosure decisions for capital market reasons as

Manuscript received April 15, 2014; revised June 26, 2014.

Jiří Strouhal is with University of Economics Prague, Prague, Czech Republic (e-mail: strouhal@vse.cz).

Monika Nikitina-Kalamäe and Natalja Gurvitš are with Tallinn University of Technology/TSEBA, Tallinn, Estonia (e-mail: monika.nikitina-kalamae@tseba.ttu.ee, natalja.gurvits@tseba.ttu.ee). follows: i) capital market transactions, ii) corporate control contests, iii) stock compensation, iv) litigation, v) proprietary costs, and vi) management talent signalling.

The link between corporate disclosure policy and analyst behaviour has also been investigated [9] as well as the relationship between disclosure level and the cost of equity capital [10], [11].

By investigating the annual reports for 2001 of 100 French firms belonging to the SBF 120 stock index, Chavent et al. [12] found that the disclosure pattern is associated with provision intensity, size, leverage, and market expectation. Companies with the highest score for disclosures have the greatest provision intensity, firm size, leverage, and market expectation.

Shareholders and other stakeholders need information while it is still fresh and the more time that passes between year-end and disclosure, the more stale the information becomes and the less value it has [13]. Timeliness of financial reporting is also considered to be the part of the fundamental financial accounting qualities. However, the on-time submission of financial reports varies from country to country depending on various factors. Numerous studies show mixed results in regards to the factors, which influence timeliness of submission the annual reports. Basu [14] and Haw et al. [15] reveal that timeliness is directly related to the net profit earned by the company. The higher the profit, the more quickly one can expect the annual report to become publicly available. Based on the information of listed Chinese firms with A-shares for 1994-1997, Haw et al. [15] found that companies are willing to report good news, prepare and submit their annual reports earlier than companies with bad news, and companies with financial loss release their annual reports the latest. This is also confirmed by the findings of Han and Wild [16] showing that the timing of earnings reports has significant and far-reaching economic consequences. In their study they found that earlier earnings releases yield negative information transfers, earnings releases yield negative (nominal) information transfers to firms that previously (subsequently) release their earnings reports, and earlier earnings releases yield negative information transfers to firms that have not yet disclosed earning [16]. According to Rosenström and Lyytimäki [17] the timeliness of information contributes to the quality and appeals of the reports and to their role as early warning tools, and increases their usability by decision-makers in short-term decision cycles.

Some studies suggest that the timeliness of the reporting largely depends on the size of the company. Large companies and the ones quoted at the stock exchange are most concerned in providing information to their 
shareholders in the most fast and efficient way. While small and micro sized companies have no reason to rush. In their studies Atiase et al. [18] claim that timelines of reporting is related to the firm size. The length of the reporting delay is inversely related to the magnitude of report period price revaluations. That is, longer delays are associated with smaller market reactions, when firm size is held constant. There is some evidence that this relation may be stronger for earnings announcements which convey "bad news" [18].

There is also an opinion that the economic decline has significantly influenced the timeliness of financial reporting making the situation worse and that the various measures implemented by different countries, like new government regulations, reporting systems etc., have made a positive impact on the on-time submission of annual reports. This opinion is supported by the studies of Vichitsarawong et al. [19] of the impact of the Asian financial crisis on conservatism and timeliness of earnings. Their studies revealed that timeliness of earnings during the crisis period were low, but improved in the post-crisis period. The results of their studies also indicated that the introduction of the corporate governance measures to stabilize financial systems and improve regulation in the four selected Asian countries had the positive impact on the conservatism and timeliness of earnings. The studies of Lai et al. [20] examined the impact of mandatory IFRS adoption on accounting conservatism in Australia. Evidence suggests the adoption of IFRS has led to a decrease in conditional conservatism (i.e. asymmetric timeliness).

There is also a relationship between the timeliness and the economic situation in the reporting country. According to McGee and Yuan [13], few studies have been published that compare the timeliness of financial reporting in transition economies and the more developed market economies. McGee [21], [22] found that companies in the Russian energy sector take a significantly longer amount of time to report financial results than do non-Russian companies in the energy and telecommunication sector.

\section{RESEARCH DESIGN}

As living currently in information society, on time data are vital for current creditors as well as for potential investors. From this perspective we did surveyed whether reputed TOP100 companies in selected countries are willing to publicly present their data.

For our analysis we opted for two countries from CEE region that entered European Union in 2004, concretely Czech Republic and Estonia. Czech Republic is reputed as one of the leading economies from the new block EU countries; Estonia is reputed as an IT leader from these countries.

Data used within our analysis were picked-up from publicly presented information in Business Registers of analyzed countries.

\section{A. Czech Case}

Based on current Czech accounting legislature all statutory audited companies shall present their financial reports within Business Register within the period of 30 days after their approval by company's general assembly.
Companies are submitting their financial reports in electronic form. Based on the Accounting Act all companies failing this obligation have to pay a penalty up to $3 \%$ of assets total. However there shall be stated that this penalty is obviously not applied in practice.

For this survey we did use the information about most successful TOP100 Czech companies as stated in public ranking and analyzed their on-time submission for the period 2007-2011. Firstly we did checked if these reports were submitted before the stated due date in each year and then counted the number of months since the final date of submission till the submitted date in order to find out the duration of the delay period.

\section{B. Estonian Case}

In order to improve the timeliness of the annual financial reporting in Estonia as of January 2010, entrepreneurs in Estonia can submit annual reports in XBRL format via the e-reporting environment of the e-Commercial Registry Company Registration Portal. This project was implemented at the national level and was among the largest in 2010 in terms of its scope and volume, by involving more than 120,000 companies. XBRL format is being increasingly recognised as the global standard for transferring business information, which ensures better availability of data. The possibility to submit a paper annual report still existed through the year 2010, but these reports could not be submitted directly to the Register but only via notary. According to the Centre of Registers and Information Systems the overall goal of the e-reporting project is to facilitate the administration of the reporting obligation as a whole. The key principle of submitting data should be that a reporting entity submits the figures required by the state once in the agreed format and in one place and the data thus submitted can be used both by the private and public sectors in line with their established rights.

Current research represents the examination of how the implementation of the e-reporting system has influenced the on-time submission of annual reports by the selected companies. In order to determine whether the new ereporting system influenced positively the on-time submission of annual reports authors have selected the annual reports submitted to the Estonian Business Register (hereinafter referred to as the register) by the most successful TOP100 Estonian companies as stated in their list published by the Estonian leading business newspaper "Äripäev" for the period 2007-2011. Authors have chosen the most successful companies supposing that they were first to react to positive changes in the reporting area. At first, authors checked if these reports were submitted before the stated due date in each year and then counted the number of months since the final date of submission till the submitted date in order to find out the duration of the delay period.

\section{RESUlts}

\section{A. Czech Case}

The authors have used the information base of the Czech Business Register (www.justice.cz), accessed in June-July 2013 and have got the information about the approximately 
500 reports of the 92 companies. From those companies significant number use as an accounting period not a calendar year, that's why the end of the accounting period fell onto consequent year.

For the year 2007 authors were able to use the annual reports of only 85 companies as some companies were established during this period or later and for some companies no reports were found in the database. For year 2011 authors could use the reports of 91 companies for the present research. This breakout is illustrated in Table I.

TABLE I: REPORTS USED FOR THE SURVEY FOR YEAR 2007-2011
\begin{tabular}{|c|c|}
\hline $\begin{array}{c}\text { Year when the report } \\
\text { was submitted }\end{array}$ & $\begin{array}{c}\text { Number of reports } \\
\text { used in the present survey }\end{array}$ \\
\hline 2007 & 85 \\
\hline 2008 & 86 \\
\hline 2009 & 90 \\
\hline 2010 & 92 \\
\hline 2011 & 91 \\
\hline Total & $\mathbf{4 4 4}$ \\
\hline
\end{tabular}

Source: author's construction based on data retrievable from Czech Business Register (www.justice.cz)

Approximately we were able to analyze around 90 companies within approached period $2007-2011$.

Table II illustrates the percentage of the annual reports submitted on time (i.e. within 30 days after approval by general assembly) and with delay. The smallest percentage of the on time submitted reports occurred in 2011 (8.8\% or 8 reports from the total of 91 ), and the highest percentage of on time submission was reached in $2009(13.3 \%$ or 12 reports from the total of 90).

TABLE II: SUBMISSION OF ANNUAL REPORTS DURING YEARS 2007-2011 BY CZECH TOP100 COMPANIES

\begin{tabular}{|c|c|c|c|}
\hline Year & $\begin{array}{c}\text { On Time } \\
\text { Submission }\end{array}$ & $\begin{array}{c}\text { Delayed } \\
\text { Submission }\end{array}$ & Total \\
\hline 2007 & $\begin{array}{c}8 \\
(9.4 \%)\end{array}$ & $\begin{array}{c}77 \\
(90.6 \%)\end{array}$ & 85 \\
\hline 2008 & $\begin{array}{c}11 \\
(12.8 \%)\end{array}$ & $\begin{array}{c}75 \\
(87.2 \%)\end{array}$ & 86 \\
\hline 2009 & $\begin{array}{c}12 \\
(13.3 \%)\end{array}$ & $\begin{array}{c}78 \\
(86.7 \%)\end{array}$ & 90 \\
\hline 2010 & $\begin{array}{c}10 \\
(10.9 \%)\end{array}$ & $\begin{array}{c}82 \\
(89.1 \%)\end{array}$ & 92 \\
\hline 2011 & $83 \%)$ & 91 \\
$(8.8 \%)$ & $\mathbf{8 9 . 0} \%$ & $\mathbf{x}$ \\
\hline $\begin{array}{c}\text { Average } \\
\text { (whole period) }\end{array}$ & $\begin{array}{c}\mathbf{1 1 . 0} \% \\
\text { Source: author's construction based on data retrievable from Czech }\end{array}$ \\
\hline
\end{tabular}

The authors also found out that the structure of the delayed submissions has not been changed significantly. There shall be stated that around $80 \%$ of delayed reports is delivered within the period of 6 months after required submission date (and $45 \%$ even within the period of 3 months). The breakdown is illustrated by the Table III.

\begin{tabular}{|c|c|c|c|c|c|c|}
\hline \multirow[t]{2}{*}{ Year } & & \multicolumn{4}{|c|}{ Delay (in months) } & \multirow[t]{2}{*}{ Total } \\
\hline & $<1$ & $1-3$ & $3-6$ & $6-12$ & $>12$ & \\
\hline 2007 & $\begin{array}{c}20 \\
(26.0 \%)\end{array}$ & $\begin{array}{c}19 \\
(24.7 \%)\end{array}$ & $\begin{array}{l}31 \\
\quad(40.2 \%)\end{array}$ & $\begin{array}{c}6 \\
(7.8 \%)\end{array}$ & $\begin{array}{c}1 \\
(1.3 \%)\end{array}$ & 77 \\
\hline 2008 & $\begin{array}{c}9 \\
(12.0 \%)\end{array}$ & $\begin{array}{c}21 \\
(28.0 \%)\end{array}$ & $\begin{array}{c}24 \\
(32.0 \%)\end{array}$ & $\begin{array}{c}19 \\
(25.3 \%)\end{array}$ & $\begin{array}{c}2 \\
(2.7 \%)\end{array}$ & 75 \\
\hline 2009 & $\begin{array}{c}9 \\
(11.5 \%)\end{array}$ & $\begin{array}{c}19 \\
(24.4 \%)\end{array}$ & $\begin{array}{c}38 \\
(48.7 \%)\end{array}$ & $\begin{array}{c}9 \\
(11.5 \%)\end{array}$ & $\begin{array}{c}3 \\
(3.9 \%)\end{array}$ & 78 \\
\hline 2010 & $\begin{array}{c}15 \\
(18.3 \%)\end{array}$ & $\begin{array}{c}23 \\
(28.0 \%)\end{array}$ & $\begin{array}{c}28 \\
(34.2 \%)\end{array}$ & $\begin{array}{c}14 \\
(17.1 \%)\end{array}$ & $\begin{array}{c}2 \\
(2.4 \%)\end{array}$ & 82 \\
\hline 2011 & $\begin{array}{c}13 \\
(15.7 \%)\end{array}$ & $\begin{array}{c}25 \\
(30.1 \%)\end{array}$ & $\begin{array}{c}31 \\
(37.3 \%)\end{array}$ & $\begin{array}{c}13 \\
(15.7 \%)\end{array}$ & $\begin{array}{c}1 \\
(1.2 \%)\end{array}$ & 83 \\
\hline
\end{tabular}

Based on this results there was also made survey among Big4 auditing groups whether these companies do present their financial reports on time - results are visible from Table IV.

TABLE IV: SUBMISSION OF ANNUAL REPORTS DURING YEARS 2007-2011 BY BIG4 COMPANIES

\begin{tabular}{|c|c|c|c|c|}
\hline Year & PwC & Deloitte & EY & KPMG \\
\hline 2007 & delay 1M & delay $8 \mathrm{M}$ & on time & delay 1M \\
\hline 2008 & delay 4M & delay 4M & delay $<1 \mathrm{M}$ & delay 3M \\
\hline 2009 & delay 1M & delay $2 \mathrm{M}$ & delay $6 \mathrm{M}$ & on time \\
\hline 2010 & delay $<1 \mathrm{M}$ & delay $6 \mathrm{M}$ & on time & delay $2 \mathrm{M}$ \\
\hline 2011 & delay $<1 \mathrm{M}$ & delay $8 \mathrm{M}$ & delay $<1 \mathrm{M}$ & on time \\
\hline Average & delay 1.4M & delay 5.6M & delay 1.4M & delay 1.2M \\
\hline
\end{tabular}

Source: author's construction based on data retrievable from Czech Business Register (www.justice.cz)

As is visible from these results, with the exemption of Deloitte Company, Big4 companies are more or less willing to submit their financial reports on time and improved their on-time measure from 2008 till nowadays.

From the performed survey is visible that majority of
Czech companies still see the obligation as presentation of sensitive data and that's why they are not very willing to submit their reports on time.

There is very interesting view of one of Czech CFOs about public presentation of reports: "Presentation of financial statements shall be obligatory-based only for purposes of shareholders and tax authorities. This legal requirement about public presentation of financial reports is a brilliant tool for competitors, customers (extortion in business relations) and potential investors (exposure of weaknesses, hostile takeover)."

\section{B. Estonian Case}

The authors have used the information base of the "Äripäev" newspaper, accessed in July-August 2013 and have got the information about the approximately 600 reports of the 99 companies. It should also be mentioned that for 94 surveyed companies the accounting period falls on the 31st of December, two companies has changed the end of the accounting period during the surveyed years and 
in 2011 for the 96 companies the end of the accounting period fell on the end of the calendar year.

Since the Restoration of the Independence in Estonia the submission process has undergone three different stages of development. Till 2002 all annual report were submitted only on paper. In the period 2002-2009 there was added a possibility to submit the annual report electronically in PDF of RTF formats. The company could choose the most suitable option. For the year 2007 authors were able to use the annual reports of only 75 companies as some companies were established during this period, the others did submitted paper report, but the date of submission was not clear and for some companies no reports were found in the database. For year 2011 authors could use the reports of 98 companies for the present research. This breakout is illustrated in Table V.

TABLE V: REPORTS USED FOR THE SURVEY FOR YEAR 2007-2011
\begin{tabular}{|c|c|}
\hline $\begin{array}{c}\text { Year when the report } \\
\text { was submitted }\end{array}$ & $\begin{array}{c}\text { Number of reports } \\
\text { used in the present survey }\end{array}$ \\
\hline 2007 & 75 \\
\hline 2008 & 85 \\
\hline 2009 & 87 \\
\hline 2010 & 96 \\
\hline 2011 & 98 \\
\hline Total & $\mathbf{4 4 1}$ \\
\hline
\end{tabular}

Source: author's construction based on Estonian Business Register Information Base

The data shows that the number of submitted reports used for the research has significantly grown due to the implementation of the e-reporting system. In Estonia a business entity has to prepare and submit to the register the annual report for the preceding year within the 6 months after the end of the year. It is also important that the number of the annual reports submitted on time has also changed significantly in 2010, which in authors' opinion is also directly related to the introduction of the e-reporting environment.

Table VI illustrates the percentage of the annual reports submitted on time and with delay. It is obvious that the smallest percentage of the on time submitted reports occurred in 2009 (67.8\% or 59 reports from the total of 87$)$, and this figure grew significantly in $2010(89.8 \%$ or 86 reports from the total of 96).

TABLE VI: SUBMISSION OF ANNUAL REPORTS DURING YEARS 2007-2011 BY ESTONIAN TOP100 COMPANIES

\begin{tabular}{|c|c|c|c|}
\hline Year & $\begin{array}{c}\text { On Time } \\
\text { Submission }\end{array}$ & $\begin{array}{c}\text { Delayed } \\
\text { Submission }\end{array}$ & Total \\
\hline 2007 & $\begin{array}{c}57 \\
(76.0 \%)\end{array}$ & $\begin{array}{c}18 \\
(24.0 \%)\end{array}$ & 75 \\
\hline 2008 & $\begin{array}{c}65 \\
(76.5 \%)\end{array}$ & $\begin{array}{c}20 \\
(23.5 \%)\end{array}$ & 85 \\
\hline 2009 & $\begin{array}{c}59 \\
(67.8 \%)\end{array}$ & $\begin{array}{c}28 \\
(32.2 \%)\end{array}$ & 87 \\
\hline 2010 & $\begin{array}{c}86 \\
(89.6 \%)\end{array}$ & $\begin{array}{c}10 \\
(10.4 \%)\end{array}$ & 96 \\
\hline 2011 & $\begin{array}{c}84 \\
(85.7 \%)\end{array}$ & $\begin{array}{c}14.3 \%) \\
\text { Average }\end{array}$ & $\begin{array}{c}\mathbf{7 9 . 1} \% \\
\text { (whole period) }\end{array}$ \\
\hline \multicolumn{4}{|c|}{ Source: author's construction based on Estonian Business Register } \\
\hline
\end{tabular}

The research confirmed that the number of the on time submitted annual reports has increased since 2010. The authors also found that the structure of the delayed submissions has changed. Normally, more than $50 \%$ of the delayed annual reports are submitted within one month after the stipulated period, which is illustrated by the Table VII.

TABLE VII: DELAYED SUBMISSION OF ANNUAL REPORTS DURING YEARS 2007-2011 BY ESTONIAN TOP100 COMPANIES

\begin{tabular}{|c|c|c|c|c|c|}
\hline \multirow[t]{2}{*}{ Year } & \multicolumn{4}{|c|}{ Delay (in months) } & \multirow[t]{2}{*}{ Total } \\
\hline & $<1$ & $1-2$ & $2-3$ & $>3$ & \\
\hline 2007 & $\begin{array}{c}9 \\
(50.0 \%)\end{array}$ & $\begin{array}{c}4 \\
(22.2 \%)\end{array}$ & $\begin{array}{c}3 \\
(16.7 \%)\end{array}$ & $\begin{array}{c}2 \\
(11.1 \%)\end{array}$ & 18 \\
\hline 2008 & $\begin{array}{c}13 \\
(65.0 \%)\end{array}$ & $\begin{array}{c}2 \\
(10.0 \%)\end{array}$ & $\begin{array}{c}1 \\
(5.0 \%)\end{array}$ & $\begin{array}{c}4 \\
(20.0 \%)\end{array}$ & 20 \\
\hline 2009 & $\begin{array}{c}19 \\
(67.9 \%)\end{array}$ & $\begin{array}{c}2 \\
(7.1 \%) \\
\end{array}$ & $\begin{array}{c}3 \\
(10.7 \%)\end{array}$ & $\begin{array}{c}4 \\
(14.3 \%) \\
\end{array}$ & 28 \\
\hline 2010 & $\begin{array}{c}5 \\
(50.0 \%)\end{array}$ & $\begin{array}{c}0 \\
(0.0 \%)\end{array}$ & $\begin{array}{c}4 \\
(40.0 \%)\end{array}$ & $\begin{array}{c}1 \\
(10.0 \%)\end{array}$ & 10 \\
\hline 2011 & $\begin{array}{c}7 \\
(50.0 \%)\end{array}$ & $\begin{array}{c}0 \\
(0.0 \%)\end{array}$ & $\begin{array}{c}5 \\
(35.7 \%) \\
\end{array}$ & $\begin{array}{c}2 \\
(14.3 \%) \\
\end{array}$ & 14 \\
\hline
\end{tabular}

Source: author's construction based on Estonian Business Register Information Base

Results clearly show that the number of companies submitting their annual reports with the delay of one to two months has decreased and reached zero in 2010. Therefore it can be stated that if the annual report is not submitted straight after the due date or with a short delay companies are no longer in a hurry and submit the report much later than requested only when they find a suitable time. Authors believe that these changes occurred due to the new possibilities of the e-reporting systems, which enabled companies to submit reports in the most efficient and convenient way.

\section{CONCLUSIONS}

Results show that majority of Czech TOP100 companies are willing to publicly present their financial reports, however with significant delay. The percentage of on-time submission obviously didn't reach the result of more than 10 $\%$. Majority of delayed reports (around $80 \%$ ) are submitted within the period of 6 months after deadline.

The implementation of the e-reporting system in Estonia has positively influenced the timeliness of the submission of the annual financial reports by rising the percentage of the reports submitted on time and shortening the delay period. It is also obvious that the new e-reporting system enabled companies to submit their annual report in a very easy and effective way requiring less time and efforts.

When linking the results of the survey approached in Czech Republic and Estonia, it shall be stated that the results varies only on first sight, as majority of Estonian companies fulfill their obligation on time (meaning 6 months after the end of accounting period). As the Czech legislature requires submitting the reports within one month after the approval by general assembly (obviously taking place around February/March of consequent year) there shall be stated that reports delayed for up to six months are technically in line with the Estonian deadline.

Authors suggest that the future research shall focus on investigation of the various factors of delay in submitting the reports. Such research would be relevant and useful as most companies in Czech Republic and Estonia are small 
and medium-sized and this study may reveal problems related to preparation and submission of annual reports and suggest further measures to improve the situation.

\section{ACKNOWLEDGMENT}

This paper is one of the research outputs of the project IGA VŠE F3/2/2014 registered at Internal Grant Agency of the University of Economics Prague.

\section{REFERENCES}

[1] F. Citro, "Disclosure level evaluation and disclosure determinant analysis: a literature review," Working Paper, University of Salerno, 2013.

[2] M. Abu-Nassar and B. A. Rutherford, "External users of financial reports in less developed countries: the case of Jordan," British Accounting Review, vol. 28, pp. 73-87, 1996.

[3] J. Arnold and P. Moizer, "A survey of the methods used by UK investment analysts to appraise investments in ordinary shares," Accounting and Business Research, vol. 14, pp. 195-207, 1984.

[4] M. Firth, "The impact of siz e, stock market listing, and auditors on voluntary disclosure in corporate annual reports," Accounting and Business Research, vol. 10, pp. 273-280, 1979.

[5] T. A. Lee and D. P. Tweedie, "Accounting information: An investigation of private shareholder usage," Accounting Business Research, vol. 6, pp. 280-291, 1975.

[6] P. M. Healy and K. G. Palepu, "Information asymmetry, corporate disclosure, and the capital markets: a review of the empirical disclosure literature," Journal of Accounting and Economics, vol. 31, no. 1-3, pp. 405-440, 2001.

[7] R. Lambert, C. Leuz, and R. Verrecchia, "Accounting information, disclosure, and the cost of capital," Journal of Accounting Research, vol. 45, no. 2, pp. 385-420, 2007.

[8] G. M. McNally, L. H. Eng, and H. C. Roy, "Corporate financial reporting in New Zealand: an analysis of user preferences, corporate characteristics and disclosure practices for discretionary information," Accounting and Business Research, pp. 11-20, 1982.

[9] M. H. Lang and R. J. Lundholm, "Corporate disclosure policy and analyst behavior," The Accounting Review, vol. 71, no. 4, pp. 467492, 1996

[10] C. A. Botosan, "Disclosure level and the cost of equity capital," The Accounting Review, vol. 72, no. 3, pp. 323-349.

[11] C. A. Botosan and M. A. Plumlee, "A re-examination of disclosure level and the expected cost of equity capital," Journal of Accounting Research, vol. 40, no. 1, pp. 21-40, 2002.

[12] M. Chavent, Y. Ding, L. Fu, H. Stolowy, and H. Wang, "Disclosure and Determinants Studies: An Extension Using the Divisive Clustering Method," European Accounting Review, vol. 15, no. 2, pp. 181-218, 2006.

[13] R. W. McGee and X. Yuan. (2008). Corporate governance and the timeliness of financial reporting: And empirical study of the people's Republic of China. [Online]. Available: http://papers.ssrn.com/sol3/papers.cfm?abstract_id=1131338

[14] S. Basu, "The conservatism principle and the asymmetric timeliness of earnings," Journal of Accounting \& Economics, vol. 24, pp. 3-37, 1997

[15] I.-M. Haw, D. Qi, and W. Wu, "Timeliness of annual report releases and market reaction to earnings announcements in an emerging capital market: The case of China," Journal of International Financial Management \& Accounting, vol. 11, pp. 108-131, 2000.

[16] J. C. Y. Han and J. J. Wild, "Timeliness of reporting and earnings information transfers," Journal of Business Finance \& Accounting, vol. 24, pp. 527-540, 1997.

[17] U. Rosenström and J. Lyytimäki, "The role of indicators in improving timeliness of international environmental reports," European Environment, vol. 16, pp. 32-44, 2006.

[18] R. K. Atiase, L. S. Bamber, and S. Tse, "Timeliness of financial reporting, the firm size effect, and stock price reactions to annual earnings announcements," Contemporary Accounting Research, pp. 526-552, 1989.

[19] T. Vichitsarawong, L. L. Eng, and G. K. Meek, "The impact of the asian financial crisis on conservatism and timeliness of earnings: Evidence from Hong Kong, Malaysia, Singapore, and Thailand,' Journal of International Financial Management \& Accounting, vol 21, pp. 32-61, 2010.

[20] C. Lai, M. Lu and Y. Shan, "Has Australian financial reporting become more conservative over time?" Accounting \& Finance, vol. 53, pp. 731-761, 2013

[21] R. W. McGee, "Timeliness of Financial reporting in the energy sector," Russian/CIS Energy \& Mining Law Journal, vol. 4, no. 2, pp 6-10, 2006.

[22] R. W. McGee, "Corporate governance in Russia: A case study of timeliness of financial reporting in the telecom industry," International Finance Review, vol. 7, pp. 365-390, 2007.

[23] Äripäev. (2012). Top100. [Online]. Available: http://leht.aripaev.ee/images/publicationimages/3b0915d6-57bc-451eb5e4-edfc3f74d0e7-Paper/issue.pdf

[24] Business Register of Czech Companies. [Online]. Available: http://www.justice.cz

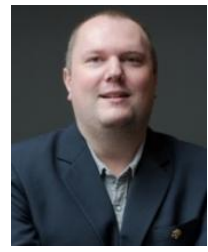

Jiří Strouhal is an associate professor at the Department of Business Economics, University of Economics Prague, Czech Republic. Within the very same institution, he gained his Ph.D. degree in 2005 and habilitation in 2012.

$\mathrm{He}$ also acts as a professional advisor in the field of accounting and corporate finance and since 2011 he is a president of Chamber of Certified Accountants Czech

Republic.

His research interests cover international accounting, financial statements analysis and corporate finance.

Monika Nikitina-Kalamäe is a lecturer at Department of Accounting, Tallinn University of Technology TSEBA, Estonia. She gained her master degree from this university in 2009.

Her research interests cover corporate financial reporting, reporting of non-for-profit organization, e-reporting, accounting education.

Natalja Gurvitš is an associate professor at Department of Accounting, Tallinn University of Technology TSEBA, Estonia. She gained her Ph.D. degree in 2002 at St. Petersburg State University in Russia.

Her research interests cover corporate financial reporting, auditing and corporate governance, environmental accounting, corporate social responsibility and professional ethics. 